Int. Arch. Allergy 1970;39:I-VIII

\title{
Contents, Vol. 39, 1970
}

Vol. 39, 1970

International Archives of Allergy andApplied Immunology

Incorporating the Transactions of the Collegium Internationale Allergologicum

Founders:

P. Kallós, W. Löffler,

Fred W. Wittich, D. Harley

Editors-in-Chief:

R. R. A. Coombs, Cambridge H. C. Goodman, Geneva F. Hahn, Freiburg/Br. P. Kallós, Helsingborg P. Miescher, Geneva

F. Milgrom, Buffalo, N.Y.

G. B. West, Epsom, Surrey

Contributing Editors:

E. L. Becker, Washington, D.C.

H. Bloch, Basel

W. E. Brogklehurst, Edinburgh

T. Broman, Göteborg

L. Businco, Roma

A. Cerletti, Basel

A. L. De Weck, Bern

P. G. H. Gell, Birmingham

I. Glazer, Tel Aviv

R. A. Good, Minneapolis, Minn.

A. Grumbach, Zurich

M. Hasek, Prague

T. Inderbitzin, Miami, Fla,

H. Isliker, Lausanne

E. A. Kabat, New York

R. Keller, Zurich

T. Ogata, Tokyo

A. Oliveira-Lima, Rio de Janeiro

Ö. Ouchterlony, Göteborg

W. Pagel, London

R. Panzani, Marseille

M. Rocha e Silva, São Paulo

I. M. Roitt, London

B. Rose, Montreal

D. Rowe, Geneva

G. Ruiz-Moreno, Buenos Aires 


\author{
E. Sorkin, Davos-Platz \\ H. Storck, Zurich \\ A. Szenberg, Lausanne \\ A. Tiselius, Uppsala \\ Z. Trnka, Geneva \\ B. H. Waksman, New Haven, Conn. \\ G. L. Waldbott, Detroit, Mich. \\ R. G. White, Glasgow
}

sut $k$

S.Karger · Basel (Switzerland) · München · New York

S. Karger, Arnold-Böcklin-Strasse 25, CH-4000 Basel 11 (Switzerland)

All rights, including that of translation into other languages, reserved.

Photomechanic reproduction (photocopy, microcopy) of this book or parts thereof without special permission of the publishers is prohibited.

(C) Copyright 1970 by S. Karger AG

Printed in Switzerland by Buchdruckerei National-Zeitung AG, Basel

Contents

Aguirre, A. R.: vide Katsh, S.

Aloj, S. M.: vide Carlomagno, M. Stella

Arbesman, C. E.: vide I $\tau$ o, K.

Arbuckle, J. B.: vide Vaerman, J. P.

Arora, Satish; Lahiri, P. K., and Sanyal, R. K.: The Role of Prostaglandin Et in Inflammatory Process in the Rat 186

Atoynatan, T.: vide Bartfeld, $H$.

Back, O.: Studies on the Lymphocytes in the Intestinal Epithelium of the Chicken.

III. Effect of Thymectomy 192

Back, O.: Studies on the Lymphocytes in the Intestinal Epithelium of the Chicken.

IV. Effect of Bursectomy 342

Barnett, Eugene V.: vide Bluestone, R.

Bartfeld, H. and Atoynatan, T.: In vitro Delayed (Cellular) Hypersensitivity in

Multiple Sclerosis to Central Nervous System Antigens 361

Beckert, W. H. and Sharkey, Mary M.: Mitogenic Activity of the Jack Bean

(Canavalia ensiformis) with Rabbit Peripheral Blood Lymphocytes . . 337

Benezra, D.; Gery, I., and Da vies, A. M.: Specificity of Blast Transformation. I.

Studies with Organ and Species-Specific Antigens 479

Benezra, D.; Gery, I., and Da vies, A. M.: Specificity of Blast Transformation. II.

Studies with Erythrocyte Antigens 488

Bianco, A. R.: vide Carlomagno, M. Stella

Bluestone, R.; Goldberg, L. S.; Cracchiolo III, Andrea, and Barnett, Eugene

V.: Detection and Characterization of DNA in Mixed (IgG-IgM) Cryo-

globulins

16

Bodammer, G. and Vogt, W.: Contraction of the Guinea-Pig Ileum Induced by

Anaphylatoxin Independent of Histamine Release 648

Borel, J. F.: Studies on Chemotaxis. Effect of Subcellular Leukocyte Fractions on Neutrophils and Macrophages 
Boss, J. H.: vide Brautbar, C.

Brautbar, C; Nelken, D.; Boss, J. H. and Superstine, E.: Autoimmune Graft

Rejection. II. Rejection of Skin Autotransplants in Rats Sensitized with

Homologous and Heterologous Skin Preparations 98

Camargo, M. E. and Ferreira, A. W.: A Microscopic Immunofluorescence Technique with

Soluble Protein Antigens Fixed to Cellulose Particles .... 292

Carlomagno, M. Stella; Bianco, A. R.; Aloj, S. M., and Vecchio, G.: Studies of

Some Immunological Properties of Thyroid Iodoproteins 391

Carnegie, P. R.: vide McPherson, T. A.

Cinader, B.: vide Naylor, D. H.

Coombs, R. R. A.; Gurner, B. W.; McConnell, I., and Munro, A.: Immuno-

globulin Determinants on Mouse Lymphocytes from Blood, Lymph

Nodes, Bone Marrow and Thymus 280

Coombs, R. R. A.; Gurner, B. W.; Wilson, Anne B.; Holm, G., and Lindgren, B.:

Rosette-Formation Between Human Lymphocytes and Sheep Red Cells

not Involving Immunoglobulin Receptors 658

Cooper, M. D.: vide Mosser, G.

Crachiolo III, Andrea: vide Bluestone, R.

Davies, A. M.: vide Benezra, D.

Dodd, V. M. B.: vide Vaz, E. M.

Elsasser, Patricia: vide Rigas, Demetrios A.

Emmerling, P.: vide Finger, $H$.

Fagerberg, E. and Wide, L.: Diagnosis of Hypersensitivity to Dog Epithelium in

Patients with Asthma Bronchiale 301

Ferrarini, M. and Kelus, A. S.: An Artificial Model for Double Mixed Agglutina tion Reaction 640

Ferreira, A. W.: vide Camargo, M. E.

Fetherstonhaugh, Pamela: The Immunogenicity and Tolerance-Inducing Ability

of Soluble Extracts of Sheep Red Blood Cell Membranes 310

Finger, H.; Emmerling, P., and Offenhammer, A.: Reduced Adjuvant Activity of

Bordetella pertussis Vaccine in Mice after Priming with an Immunogenic

Threshold Dose 45

Fröland, S. S. and Natvig, J. B.: Effect of Polyspecific Rabbit Anti-Immuno-

globulin Antisera on Human Lymphocytes in vitro 121

Gery, I.: vide Benezra, D.

Gewurz, H.; Moberg, A.; Simmons, R.; Pollara, B.; Soll, R., and Najarian, S.:

Reactivities to Horse Anti-Lymphocyte Globulin. I. Induction of Immun-

ologic Tolerance in Man 113

Gewurz, H.; Pickering, R. J.; Moberg, A.; Simmons, R. L.; Good, R. A., and Najarian, J. S.:

Reactivities to Horse Anti-Lymphocyte Globulin. II. Serum Sickness Nephritis with

Complement Alterations in Man .... 210

Gleich, G. J.: vide Michel, B.

Goldberg, L. S.: vide Bluestone, R.

Good, R. A.: vide Gewurz, H.

Good, R. A.: vide Mosser, G.

Goodfriend, L.: vide Radermecker, M. 
Gordon, Eve B.: vide Wiener, A. S.

Greaves, M. W.: vide Søndergaard, J.

Gurner, B. W.: vide Coombs, R. R. A.

Hahn, F.; Kretzschmar, R.; Teschendorf, H. J., and Mitze, R.: Role of Histaminase (Diamine Oxidase) in Disappearance of Plasma Histamine in Anaphylaxis and after Histamine Injection 449

Häkkinen, I. and $\Lambda$ 'irtanen, S.: The Appearance of Blood Group and Organ-

Specific Antigens in Human Gastric Glycoproteins 272

Hecht, F.: vide Rigas, D. A.

Heilman, Dorothy H.: Mitogenic Activity of Bacterial Fractions in Lymphocyte

Cultures. Endotoxins and Other Derivatives of Gram-Negative Bacteria 415

Heremans, J. F.: vide Vaerman, J. P.

Hicks, R. and Skeldon, N.: The Influence of Adjuvants on Antibody Production

and Anaphylactic Hypersensitivity in the Guinea Pig 234

Holm, G.: vide Coombs, R. R. A.

I $\tau$, K.; Wicher, K., and Arbesman, C. E.: Comparison of Two Myeloma IgE by

Monkey Antiserum to Human IgE 178

Jones, J. M. and Schwab, J. H.: Immune Response to Cell Wall and Tissue Antigens

in Rabbits Injured with Streptococcal Cell Wall Fragments 445

Katsh, S.; Aguirre, A. R.; Katsh, Grace F., and Willson, J. T.: Lysosomal

Activity in Testes of Guinea Pigs Immunized with Aspermatogenic

Antigen $\quad 496$

Katsh, Grace F.: vide Katsh, S.

Kelus, A. S.: vide Ferrarini, M.

Khera, K.: vide Perelmutter, L.

Konishi, K.: vide Okada, S.

Korngold, L.: On the Class Specificity of Anti-Immunoglobulin Antisera ....

Kretzschmar, R.: vide Hahn, F.

Kurata, Y.: vide Okada, S.

Lahiri, P. K.: vide Arora, Satish

Lee, Jean W.; Metcalf, Robert W., and Ryan, Wayne L.: Effect of Freund's

Complete Adjuvant on Lysosomal Enzymes 609

Leikola, J. and Pasanen, V. J.: Influence of Antigen Receptor Density on Agglu

tination of Red Blood Cells 352

Levine, B. B. and Vaz, N. M.: Effect of Combinations of Inbred Strain, Antigen, and Antigen Dose on Immune Responsiveness and Reagin Production in the Mouse. A Potential Mouse Model for Immune Aspects of Human

Atopic Allergy $\quad 156$

Levis, W. R.: vide Robbins, J. H.

Lindgren, B.: vide Coombs, R. R. A.

McConnell, I.: vide Coombs, R. R. A.

McPherson, T. A.; Robson, G. S. M., and Carnegie, P. R.: Is Encephalitogenic

Basic Protein in Human Cerebrospinal Fluid? 566

Matsuda, T.: vide Okada, S.

Maurer, P. H.; Merryman, C. F., and Stylos, W. A.: Antigenicity of Polypeptides (Poly- $\alpha$-Amino Acids). Distribution of Sheep Antibodies to Dini- 
trinophenyl-(DNP) Conjugates of Polymers of $\alpha$-L-Amino Acids of Vary

ing Electrical Charge 435

Maurer, P. H.: vide Stylos, W. A.

Merryman, C. F.: vide Maurer, P. H.

Merryman, C. F.: vide Stylos, W. A.

Metcalf, Robert E.: vide Lee, Jean W.

Michel, B.; Russel II, Th.; Winkelmann, R. K., and Gleich, G. J.: Release of

Kinins from Site of Wheal-and-Flare Allergic Skin Reactions $\quad 616$

Mitze, R.: vide Hahn, F.

Moberg, A.: vide Gewurz, H.

Monterio, M. R.: vide Vaz, E. M.

Moor-Jankowski, J.: vide Wiener, A. S.

Morein, B.: Immunity against Parainfluenza-3 Virus in Cattle. IgA in Nasal

Secretions 403

Mosser, G.; Good, R. A., and Cooper, M. D.: The Immune Responses and

Lymphoid Tissues of Neonatally Thymectomized, X-Irradiated Mice . . 62

Munro, A.: vide Coombs, R. R. A.

Najarian, J. S.: vide Gewurz, H.

Natvig,J. B.: vide Fröland, S. S.

Naylor, D. H. and Cinader, B.: Inheritance, Hormonal Regulation and Properties of Polymorphic Murine Antigens Mud 1 and Mud2 511

Naylor, D. H. and Cinader, B.: Derivatives of the Complement Component MuBl (C5mu) and Separation of a Factor Involved in the Conversion of MuB1

to MuBlf 540

Neher, G. H. and Siegel, B. V.: Ultrastructure of the Primary Immune Response.

Development of 19S Antibody-Producing Cells 133

Nelken, D.: vide Brautbar, C.

Nordç¿vist, B. and Rorsman, H.: In vitro Aggregation of Human Blood Cells in

Tuberculin Allergy 172

Offenhammer, A.: vide Finger, H.

Okada, S.; Kurata, Y.; Konishi, K., and Matsuda, T.: Immunological Studies of

Insoluble Lipoproteins. III. Characterization of the Lipoprotein-Bound

Thyroid Gland-Specific Antigen

6

Pasanen, V. J.: vide Leikola, J.

Perelmutter, L. and Khera, K.: A Study on the Detection of Human Reagins

with Rat Peritoneal Mast Cells

27

Pickering, R. J.: vide Gewurz, H.

Pollara, B.: vide Gewurz, H.

Radermecker, M.; Goodfriend, L., and Rose, B.: Inhibition of Reagin-Induced

PCA in Monkeys by Injection of Heterologous Serum

Richter, W.: Absence of Immunogenic Impurities in Clinical Dextran Tested by

Passive Cutaneous Anaphylaxis 469

Rigas, Demetrios A.; Elsasser, Patricia, and Hecht, Frederick: Impaired in

vitro Response of Circulating Lymphocytes to Phytohemagglutinin in

Down's Syndrome: Dose- and Time-Response Curves and Relation to

Cellular Immunity $\quad 587$ 
Rigas, D. A.; Tisdale, Virginia V., and Hecht, F.: Transformation of Blood Lymphocytes in Ataxia telangiectasia. Dose and Time Response to Phyto hemagglutinin 221

Robbins, J. H. and Levis, W. R.: 'Delayed' Peaks of DNA Synthesis in Phytohemagglutinin-Stimulated Human Leucocyte Cultures $\quad 580$

Robson, G. S. M.: vide McPherson, T. A.

Rorsman, H.: vide Nordç ¿vist, B.

Rose, B.: vide Radermecker, M.

Rovve, D. S. and Wood, C. B. S.: The Measurement of Serum Immunoglobulin E

Levels in Healthy Adults and Children and in Children with Allergic

Asthma 1

Russell II, Th. : vide Michel, B.

Ryan, Wayne L.: vide Lee, Jean W.

Sanyal, R. K.: vide Arora, Satish

Sharkey, Mary M.: vide Beckert, W. H.

Siegel, B. V.: vide Neher, G. H.

Silveira, I. H. S.: vide Vaz, E. M.

Simmons, R. L.: vide Gewurz, H.

Skeldon, N.: vide Hicks, R.

Socha, W. W.: vide Wiener, A. S.

Soll, R.: vide Gewurz, H.

Søndergaard, J. and Greaves, M. W.: Recovery of a Pharmacologically Active

Fatty Acid During the Inflammatory Reaction, Invoked by Patch Testing

in Allergic Contact Dermatitis

56

Superstine, E.: vide Brautbar, C.

Schwab, J. H.: vide Jones, J. M.

Stylos, W. A.; Merryman, C. F., and Maurer, P. H.: Antigenicity of Poly- $\alpha-$

Amino Acids. Distribution of Sheep Antibodies to Polymers of $\alpha$-L-

Amino Acids of Varying Net Electrical Charge and Lysozyme 381

Stylos, W. A.: vide Maurer, P. H.

Tengerdy, R. P.: Immune Response at High Altitude 426

Teschendorf, H. J.: vide Hahn, F.

Tisdale, Virginia V.: vide Rigas, D. A.

Tizard, I. R.: Macrophage Cytophilic Antibody in Mice. The Relationship between the

Adherence of Antigen to Macrophages Mediated by Macro-phage-Cytophilic Antibodies and

Opsonic Adherence Antibodies .... 201

Vaerman, J. P.; Arbuckle, J. B., and Heremans, J. F.: Immunoglobulin A in Pig.

II. Sow's Colostral and Milk IgA: Quantitative Studies and Molecular Size

Estimation 323

Vaz, E. M.; Silveira, I. H. S.; Dodd, V. M. B.; Monteiro, M. R., and Vaz, N.

M.: Anaphylactic Antibodies in the Mouse. Relationship to Mast Cell

Degranulation During in vivo Anaphylactic Reactions $\quad 459$

Vaz, N. M.: vide Levine, B. B.

Vaz, N. M.: vide Vaz, E. M.

Vecchio, G.: vide Carlomagno, M. Stella

Virtanen, S.: vide Häkkinen, I. 
Vogt, W.: vide Bodammer, G.

Wicher, K.: vide I $\tau$, $\mathrm{K}$.

Wide, L.: vide Fagerberg, E.

Wiener, A. S.; Gordon, Eve B.; Socha, W. W., and Moor-Jankowski, J.: Further

Observations on the Immunological Relationships among Serum Glob

ulins of Man and Other Primates, Revealed by a Serological Inhibition

Test 368

Willson, J. T.: vide Katsh, S. Wilson, Anne B.: vide Coombs, R. R. A. Winkelmann, R. K.: vide Michel, B. Wood, C. B. S.: vide Rowe, D. S.

Proceedings: 2nd International Symposium on Immunodermatology. . 105

Book Reviews IIl,334,664

News Items $\quad 112,336$

Erratum $\quad 664$ 